\title{
KEEFEKTIFAN HANDRUB DALAM MENURUNKAN ANGKA KUMAN DI RUMAH SAKIT PKU MUHAMMADIYAH GOMBONG KABUPATEN KEBUMEN TAHUN 2017
}

\author{
Masrur Puji Pangestu ${ }^{*}$, Zaeni Budiono ${ }^{* *}$ ) \\ Jurusan Kesehatan Lingkungan, Politeknik Kesehatan Kemenkes Semarang, \\ Jl.Raya Baturaden KM 12 Purwokerto, Indonesia
}

\begin{abstract}
Abstrak
Upaya mengatasi kejadian Infeksi Nosokomial salah satunya adalah dengan hand hygiene, karena tangan merupakan media transmisi patogen tersering di rumah sakit. Dalam pelaksanaan program hand hygiene Rumah Sakit PKU Muhammadiyah Gombong awalnya menggunakan handrub buatan pabrik, karena terkendala biaya, maka bagian farmasi Rumah Sakit PKU Muhammadiyah Gombong membuat handrub sendiri. Penelitian ini bertujuan untuk mengetahui keefektifan handrub dalam menurunkan angka kuman pada telapak tangan perawat di Rumah Sakit PKU Muhammadiyah Gombong. Jenis penelitian ini adalah deskriptif analitik. Subyek penelitian adalah perawat di lima ruang rawat inap, yaitu ruang barokah, salma, husna, hidayah, dan inayah yang bekerja pada shift pagi sebanyak lima belas orang dengan masing-masing ruangan tiga perawat. Hasil penelitian menunjukan rata-rata angka kuman pada telapak tangan sebelum menggunakan handrub adalah $64,867 \mathrm{CFU} / \mathrm{cm}^{2}$ dan rata-rata angka kuman pada telapak tangan sesudah menggunakan handrub adalah 26,867 CFU/ $\mathrm{cm}^{2}$, sedangkan keefektifan handrub dalam menurunkan angka kuman adalah 81,934\%. Simpulan dari penelitian adalah keefektifan handrub dalam menurunkan angka kuman di Rumah Sakit PKU Muhammadiyah Gombong sebesar 81,934\%. Sebaiknya handrub dibuat sesuai prosedur yang direkomendasikan oleh WHO (World Health Organization).
\end{abstract}

Kata kunci: kesehatan lingkungan; angka kuman; handrub

\begin{abstract}
The prevention of nosocomial infections one of them is hand hygiene, because the hand is the most common media on transmitting pathogen in the hospital. Implementation program of hand hygiene in Hospital PKU Gombong initially using artificial handrub factory, due to constrained charge, then part of hospital pharmacy PKU Gombong make handrub himself. This research aims to know the effectiveness of handrub in lowering the number of germs on the hands of nurses in hospitals PKU Gombong. Type of this research is descriptive analytic. The subject of research is the nurse in five inpatient space, i.e. space barokah, salma, husna, guidance, and inayah who work on shift as many as fifteen people with each room three nurses. Results of the study showed the average number of germs on hands before using the handrub is $64.867 \mathrm{CFU} / \mathrm{cm}^{2}$ and the average number of germs on hands after using handrub is $26.867 \mathrm{CFU} / \mathrm{cm}^{2}$, whereas effectiveness handrub in lowering the number of germs is $81.934 \%$. Summary of the research is the effectiveness of handrub in lowering the number of germs in hospitals PKU Gombong of $81.934 \%$. Preferably handrub made according the procedure recommended by the WHO (World Health Organization).
\end{abstract}

Keywords: environmental health; the germ; handrub 


\section{Pendahuluan}

Undang-undang Republik Indonesia Nomor 44 Tahun 2009 tentag Rumah Sakit menyatakan bahwa, setiap pasien mempunyai hak memperoleh keamanan dan keselamatan dirinya selama dalam perawatan di rumah sakit. Rumah sakit adalah institusi pelayanan kesehatan yang menyelenggarakan pelayanan kesehatan perorangan secara paripurna yang menyediakan pelayanan rawat inap, rawat jalan, dan gawat darurat.

Rumah sakit sebagai sarana pelayanan kesehatan pada dasarnya tidak lepas dari pengobatan dan perawatan yang dilakukan oleh tenaga kesehatan yang salah satunya adalah perawat. Perawat dalam melakukan asuhan keperawatan berinteraksi langsung dan tidak langsung dengan pasien yang dirawat di rumah sakit. Keadaan ini akan memudahkan terjadinya penularan penyakit infeksi terutama infeksi silang baik dari pasien ke pasien yang dirawat di rumah sakit maupun antar pasien dengan petugas rumah sakit. Infeksi yang terjadi pada pasien yang sedang dalam proses asuhan keperawatan ini disebut dengan Infeksi Nosokomial (Darmadi, 2008).

Infeksi Nosokomial atau infeksi yang diperoleh di rumah sakit adalah infeksi yang tidak diderita pasien saat masuk rumah sakit melainkan setelah \pm 72 jam berada di tempat tersebut (Karen Adams dan Janet M. Corrigan, 2003). Infeksi Nosokomial saat ini merupakan salah satu penyebab meningkatnya angka kesakitan (morbidity) dan angka kematian (mortality) di rumah sakit, sehingga masih menjadi masalah kesehatan baru, baik di negara berkembang maupun di negara maju (Darmadi, 2008). Penelitian yang dilakukan oleh Ratna Nugraheni, Suhartono, dan Sriwinarni di RSUD Setjonegoro Kabupaten Wonosobo dari bulan Juli 2009 hingga tahun 2011 menunjukkan prevalensi angka kejadian Infeksi Nosokomial pada semester II tahun 2009 (2,67), semester I dan II tahun 2010 (3,12 dan 4,36), serta semester I dan II tahun 2011 (9,68 dan 19,71) per 1000 pasien rawat inap. Proporsi kejadian Infeksi Nosokomial terbanyak menurut ruang adalah di Ruang Edelweis (47,36\%) tahun 2009, di Ruang Bougenville (bedah) $(65,3 \%)$ tahun 2010 dan di Ruang Anggrek (19,47\%) tahun 2011. Distribusi menurut waktu rawat inap (bulan) proporsi tertinggi pada bulan Juli 2009 (36,84\%), bulan Maret dan Agustus 2010 (16,32\%), bulan November 2011 (19,47\%). Distribusi menurut jenis kelamin proporsi tertinggi ditemukan pada perempuan untuk tahun 2009 dan 2010 (78,94\% dan 63,26\%), dan laki-laki (51,05\%) pada tahun 2011.

Upaya mengatasi kejadian Infeksi Nosokomial telah dilakukan, salah satunya adalah dengan hand hygiene. Ditetapkannya hand hygiene sebagai salah satu

\footnotetext{
${ }^{*}$ E-mail: masrurpujipangestu@gmail.com

${ }^{* *}$ E-mail: pakzaeni@gmail.com
}

upaya dalam mengatasi Infeksi Nosokomial adalah karena tangan merupakan media transmisi patogen tersering di rumah sakit, termasuk tangan tenaga medis dan paramedis (Tietjen et al., 2004). Standar SKP.5 Akreditasi Rumah Sakit 2012/ IPSG Joint Commission International juga mensyaratkan rumah sakit untuk memiliki program kebersihan tangan (hand hygiene).

Rumah Sakit PKU Muhammadiyah Gombong, Kebumen merupakan Rumah Sakit Swasta Tipe C dengan pelayanan pasien 24 jam yang mampu memberikan pelayanan kedokteran spesialis terbatas dan menjadi rumah sakit rujukan puskesmas. Dalam pelaksanaan program hand hygiene Rumah Sakit PKU Muhammadiyah Gombong awalnya menggunakan handrub buatan pabrik, karena terkendala biaya, maka bagian farmasi Rumah Sakit PKU Muhammadiyah Gombong membuat handrub sendiri. Sebelumnya pihak rumah sakit belum pernah melakukan pengukuran angka kuman sebelum dan sesudah menggunakan handrub buatan pabrik, sedangkan untuk handrub yang mereka buat sendiri sudah dilakukan pengukuran angka kuman secara rutin setiap satu bulan sekali, tetapi dalam pengambilan sampelnya dilakukan secara sporadis yaitu sewaktu-waktu dan bukan pada orang yang belum sama sekali menggunakan handrub tersebut, sehingga keefektifan dari handrub tersebut belum diketahui. Keefektifan yang dimaksud di sini adalah kemampuan handrub dalam menurunkan angka kuman pada telapak tangan perawat di Ruang Rawat Inap Rumah Sakit PKU Muhammadiyah Gombong.

Berdasarkan uraian di atas peneliti tertarik untuk melakukan penelitian dengan judul "Keefektifan Handrub dalam Menurunkan Angka Kuman di Rumah Sakit PKU Muhammadiyah Gombong Kabupaten Kebumen Tahun 2017”.

Permasalahan handrub di Rumah Sakit PKU Muhammadiyah Gombong yaitu dalam pengambilan sampel angka kuman dilakukan secara sporadis yaitu sewaktu-waktu dan bukan pada orang yang belum sama sekali menggunakan handrub tersebut, sehingga keefektifan dari handrub tersebut belum diketahui.

Tujuan penelitian ini untuk mengetahui keefektifan handrub dalam menurunkan angka kuman pada telapak tangan perawat di Ruang Rawat Inap Rumah Sakit PKU Muhammadiyah Gombong Kabupaten Kebumen.

\section{Bahan dan Metode}

Penelitian ini bersifat deskriptif analitik, yang bertujuan untuk mengetahui keefektifan handrub dalam menurunkan angka kuman di Rumah Sakit PKU Muhammadiyah Gombong. Pengumpulan data dilakukan dengan cara pemeriksaan laboratorium, observasi, wawancara, serta penelusuran arsip dan dokumen. Instrumen yang digunakan berupa satu set alat 
laboratorium untuk menghitung angka kuman dan kuesioner.

\section{Hasil dan Pembahasan}

a. Gambaran Umum Rumah Sakit

Rumah Sakit PKU Muhammadiyah Gombong terletak di Jalan Yos Sudarso No. 461 Gombong dengan luas lahan rumah sakit yang digunakan sebagai tempat pelayanan kesehatan seluas $17.028 \mathrm{~m}^{2}$. Luas bangunan yang ada adalah $4.774 \mathrm{~m}^{2}$. Pelayanan dan Unit Rumah Sakit PKU Muhammadiyah Gombong yang diberikan berupa Pelayanan Pelanggan Rawat Jalan, Pelayanan Rawat Inap, Ruang Pemeliharaan Sarana dan Prasarana. Jenis dan Jumlah Tenaga Kerja yang dimiliki berupa 60 orang tenaga medis, 208 orang tenaga paramedic, 64 orang penunjang tenaga medis dan 169 orang non-medis. Rumah Sakit PKU Muhamadiyah Gombong merupakan rumah sakit swasta dengan kepemilikan yayasan Muhammadiyah dan berstatus rumah sakit dengan tipe $\mathrm{C}$ yang yang mampu memberikan pelayanan kedokteran spesialis terbatas dan dapat menjadi rumah sakit rujukan puskesmas yang saat ini sedang dalam proses akreditasi menuju rumah sakit tipe B Pendidikan Utama.

\section{b. Jenis Handrub}

Berdasarkan hasil wawancara dengan pihak farmasi, jenis handrub yang digunakan di Rumah Sakit PKU Muhammadiyah Gombong sudah menggunakan bahan alkohol, sehingga sudah memenuhi saran dari WHO.

\section{c. Komposisi Handrub}

Berdasarkan hasil wawancara dengan pihak farmasi Rumah Sakit PKU Muhammadiyah Gombong, untuk membuat satu liter handrub komposisi yang digunakan sebagai berikut :

1) Alkohol 95\% sebanyak $824 \mathrm{ml}$

2) Perhidrol (H2O2) 50\% sebanyak 2,5 ml

3) Oilum rose (minyak mawar) sebanyak $2 \mathrm{ml}$

4) Gliserin (sebutan untuk gliserol >95\%) sebanyak 14,5 $\mathrm{ml}$

5) Aquades $157 \mathrm{ml}$

Menurut WHO (2009), ada dua formulasi handrub yang direkomendasikan. Pihak farmasi dalam membuat handrub mengacu pada formulasi 1, tetapi masih belum tepat karena alkohol yang seharusnya digunakan adalah alkohol 96\% sebanyak 833,3 ml ternyata yang digunakan alkohol 95\% sebanyak $842 \mathrm{ml}$, $\mathrm{H}_{2} \mathrm{O}_{2}$ yang seharusnya $\mathrm{H}_{2} \mathrm{O}_{2} 3 \%$ sebanyak $41 \mathrm{ml}$ ternyata yang digunakan $\mathrm{H}_{2} \mathrm{O}_{2} \quad 50 \%$ sebanyak 2,5 ml. Untuk gliserol 98\% sebanyak 14,5 ml sudah tepat sesuai saran dari WHO. Pihak farmasi menambahkan oilium rose (minyak mawar) sebagai pengharum, karena apabila tidak ditambah bahan tersebut, bau dari handrub cukup menyengat di hidung. WHO sendiri tidak mempermasalahkan penambahan pengharum pada handrub. Pada penambahan air suling (aquades) atau air yang telah di rebus tidak ada takaran khusus, hanya ditambahkan sampai handrub tepat $1000 \mathrm{ml}$.

\section{d. Proses Pembuatan Handrub}

Berdasarkan hasil wawancara dengan pihak farmasi Rumah Sakit PKU Muhammadiyah Gombong, proses pembuatan handrub sebagai berikut :

1) Siapkan alat dan bahan.

Alat :

a) Labu takar $1000 \mathrm{ml}$

b) Corong

c) Beaker glass

d) Pipet

Bahan :

a) Alkohol 95\% sebanyak $824 \mathrm{ml}$

b) Perhidrol $\left(\mathrm{H}_{2} \mathrm{O}_{2}\right) 50 \%$ sebanyak $2,5 \mathrm{ml}$

c) Oilum rose (minyak mawar) sebanyak $2 \mathrm{ml}$

d) Gliserin sebanyak 14,5 ml

e) Aquades $157 \mathrm{ml}$

2) Masukkan satu persatu bahan ke dalam labu takar.

3) Setelah semua bahan dimasukkan, kocok perlahan supaya semua bahan tercampur kemudian pindahkan ke botol yang berukuran $1.000 \mathrm{ml}$.

4) Setelah itu segera tutup botol dengan rapat untuk menghindari penguapan.

5) Pindahkan handrub ke botol ukuran $500 \mathrm{ml}$.

Pihak farmasi tidak membuat handrub dalam tangki, melainkan membuat tiap 1.000 ml. Ada satu hal yang kurang tepat dilakukan oleh pihak farmasi yaitu tidak menjaga handrub yang sudah jadi dalam botol selama 72 jam. Seharusnya handrub yang sudah dibotol dijaga 72 jam, karena tujuan dijaga 72 jam adalah supaya memberi kesempatan bagi $\mathrm{H}_{2} \mathrm{O}_{2}$ memusnahkan spora yang terdapat pada alkohol atau botol/ tangki.

\section{e. Pendistribusian Handrub}

Berdasarkan hasil observasi, botol handrub yang digunakan di semua ruangan rumah sakit berukuran 500 ml, seharusnya ada perbedaan ukuran botol di kamar operasi yaitu menggunakan botol berukuran 1 liter. Sementara untuk botol yang berukuran $100 \mathrm{ml}$, di Rumah Sakit PKU Muhammadiyah Gombong belum tersedia. Handrub yang sudah jadi keesokan harinya langsung didistribusikan terkadang setelah jadi langsung didistribusikan. Hal tersebut terjadi karena persedian handrub yang kurang. Handrub yang belum dijaga selama 72 jam seharusnya tidak boleh didistribusikan, karena dimungkinkan masih terdapat spora pada alkohol atau botol/ tangki.

\section{f. Proses Pembersihan dan Desinfeksi Botol Handrub}

Berdasarkan hasil wawancara dengan pihak yang mebersihkan dan mendesinfeksi botol handrub di Rumah Sakit PKU Muhammadiyah Gombong, proses 
pembersihan dan desinfeksi botol handrub sebagai berikut :

1) Siapkan ember besar, kemudian diisi air 10 liter.

2) Masukkan desinfektan (desinfektan yang digunakan adalah merek aniosyme) sebanyak $50 \mathrm{ml}$.

3) Lepaskan botol dari tutupnya kemudian rendam di air yang telah diberi desinfektan selama 15 menit.

4) Setelah itu bersihkan botol dengan cara disikat bagian luar dan dalamnya.

5) Kemudian bilas menggunakan air bersih.

6) Tiriskan botol, lalu simpan.

Proses pembersihan dan desinfeksi botol sudah memenuhi saran dari WHO. Botol yang digunakan tidak tahan panas, sehingga tidak dilakukan perebusan, dan desinfeksi botol menggunakan bahan kimia. Desinfektan yang digunakan adalah desinfektan yang biasa digunakan untuk mencuci peralatan medis yang telah digunakan untuk operasi.

g. Hasil Angka Kuman dan Keefektifan Handrub

Tabel 1 Hasil Angka Kuman dan Keefektifan Handrub

\begin{tabular}{|c|c|c|c|c|}
\hline \multirow[b]{2}{*}{ No. } & \multirow[b]{2}{*}{$\begin{array}{c}\text { Perawat } \\
\text { (orang/ } \\
\text { ruang) }\end{array}$} & \multicolumn{2}{|c|}{ Hasil } & \multirow[b]{2}{*}{$\begin{array}{c}\text { Efektifitas } \\
(\%)\end{array}$} \\
\hline & & $\begin{array}{c}\text { Sebelum } \\
(\mathrm{CFU} \\
\left./ \mathrm{cm}^{2}\right)\end{array}$ & $\begin{array}{c}\text { Sesudah } \\
(\mathrm{CFU} / \\
\left.\mathrm{cm}^{2}\right)\end{array}$ & \\
\hline 1. & Barokah 1 & 64 & 0 & -100 \\
\hline 2. & Barokah 2 & 102 & 78 & $-23,529$ \\
\hline 3. & Barokah 3 & 17 & 0 & -100 \\
\hline 4. & Husna 1 & 19 & 2 & $-89,473$ \\
\hline 5. & Husna 2 & 97 & 31 & $-68,041$ \\
\hline 6. & Husna 3 & 104 & 56 & $-46,153$ \\
\hline 7. & Salma 1 & 10 & 0 & -100 \\
\hline 8. & Salma 2 & 307 & 201 & $-34,527$ \\
\hline 9. & Salma 3 & 17 & 0 & -100 \\
\hline 10. & Hidayah 1 & 9 & 0 & -100 \\
\hline 11. & Hidayah 2 & 42 & 0 & -100 \\
\hline 12. & Hidayah 3 & 15 & 0 & -100 \\
\hline 13. & Inayah 1 & 56 & 0 & -100 \\
\hline 14. & Inayah 2 & 7 & 0 & -100 \\
\hline 15. & Inayah 3 & 107 & 35 & $-67,289$ \\
\hline \multicolumn{2}{|c|}{ Rata-rata } & 64,867 & 26,867 & $-81,934$ \\
\hline
\end{tabular}

Ketika subjek menggunakan handrub, peneliti memperhatikan langkah-langkah dan durasi atau waktu penggunaan handrub apakah sudah sesuai dengan saran dari WHO. Hasil dari pengamatan peneliti, semua subjek sudah melakukan langkah-langkah penggunaan handrub dengan benar namun masih ada beberapa subjek yang durasi dalam menggunakan handrub belum sesuai saran WHO, yaitu subjek barokah 2, husna 1, dan inayah 3. Menurut Lucet et al., (2002), faktor tentang durasi atau lamanya mencuci tangan juga berpengaruh terhadap angka kuman yang dihasilkan. Mencuci tangan sesuai durasi yang telah ada dan ditetapkan oleh WHO, yaitu 40-60 detik dapat menurunkan jumlah angka bakteri di tangan. Berdasarkan pengamatan peneliti untuk subjek yang angka kumannya masih tinggi, durasi penggunaan handrub tidak sesuai dengan saran dari WHO sehingga menyebabkan tingginya angka kuman pada telapak tangan.

Hasil negatif menunjukan bahwa handrub tersebut efektif menurunkan angka kuman sebesar 81,934\%. Perbedaan keefektifan tiap subjek dipengaruhi oleh berbagai faktor antara lain langkah-langkah penggunaan handrub serta durasi penggunaannya. Pada subjek dengan keefektifan $100 \%$, subjek sudah melakukan langkah-langkah penggunaan serta durasinya sesuai dengan saran WHO. Sementara subjek dengan keefektifan kurang dari 100\%, subjek sudah melakukan langkah-langkah penggunaan handrub dengan benar, tetapi ada beberapa subjek yang durasi penggunaanya yang belum sesuai dengan saran WHO, yaitu barokah 2, husna 1, dan inayah 3. Ada subjek yang sudah menggunakan handrub dengan langkah-langkah dan durasi yang tepat tetapi kefeektifannya belum mencapai $100 \%$ yaitu subjek husna 2, husna 3, dan salma 2, hal itu disebabkan faktor komposisi dan proses pembuatan handrub yang belum sesuai dengan saran WHO. Berdasarkan penelitian Retno Wuriyatmi (2016) keefektifan handrub jika dibuat sesuai saran WHO, kefektifannya mencapai $90,17 \%$.

\section{Kesimpulan}

a. Jenis handrub yang digunakan di Rumah Sakit PKU Muhammadiyah Gombong sesuai dengan saran WHO yaitu alkohol.

b. Komposisi handrub masih belum sesuai dengan saran WHO.

c. Proses pembuatan handrub secara keseluruhan belum sesuai saran WHO, karena handrub yang sudah jadi tidak dijaga dalam waktu 72 jam.

d. Pendistribusian handrub pada ruang selain kamar operasi sudah tepat, tetapi pada kamar operasi botol handrub harus diganti dengan yang berukuran 1 liter. Selain itu pihak farmasi belum menyediakan handrub dengan botol $100 \mathrm{ml}$ untuk penggunaan individual. Handrub yang sudah jadi keesokan harinya langsung didistribusikan terkadang setelah jadi langsung didistribusikan. Hal tersebut terjadi karena persedian handrub yang kurang.

e. Proses pembersihan dan desinfeksi botol handrub sudah sesuai dengan saran WHO.

f. Angka kuman telapak tangan sebelum menggunakan handrub yang terendah adalah subjek inayah 2 dengan jumlah angka kuman $7 \mathrm{CFU} / \mathrm{cm}^{2}$, sedangkan angka kuman tertinggi adalah pada subjek salma 2 dengan jumlah angka kuman $307 \mathrm{CFU} / \mathrm{cm}^{2}$. Rata-rata angka kuman pada telapak tangan sebelum menggunakan handrub adalah 64,867 CFU/ $\mathrm{cm}^{2}$. Angka kuman telapak tangan sesudah menggunakan handrub yang terendah pada subjek barokah 1 , barokah 3 , salma 1 , salma 3, 
hidayah 1 , hidayah2, hidayah 3 , inayah 1 , dan inayah 2 dengan jumlah angka kuman $0 \mathrm{CFU} / \mathrm{cm}^{2}$, sedangkan angka kuman tertinggi pada subjek salma 2 dengan jumlah angka kuman $201 \mathrm{CFU} / \mathrm{cm}^{2}$. Rata-rata angka kuman setelah menggunakan handrub adalah 26,867 $\mathrm{CFU} / \mathrm{cm}^{2}$.

g. Keefektifan handrub dalam menurunkan angka kuman tertinggi adalah pada subjek barokah 1 , barokah 3 , salma 1 , salma 3 , hidayah 1 , hidayah 2 , hidayah 3 , inayah 1 dan inayah 2 dengan kefektifan $-100 \%$. Sementara efektifitas terendah pada subjek barokah 2 dengan kefektifan $-23,529 \%$. Rata-rata keefektifan handrub sebesar $-81,934 \%$. Hasil negatif menunjukan bahwa handrub tersebut efektif menurunkan angka kuman sebesar 81,934\%.

\section{Ucapan Terima Kasih}

Peneliti mengucapkan banyak terima kasih kepada pihak Rumah Sakit PKU Muhammadiyah Gombong karena sudah memberikan ijin penelitian, serta seluruh pihak yang telah membantu terselesaikannya penelitian ini.

\section{Daftar Pustaka}

Adams K. dan Corrigan J.M, 2003, Committee on Identifying Priority Areas for Quality Improvement, Priority Areas for National Action: Transforming Health Care National Academies Press, at lkpkeperawatan.blogspot.co.id/ 2014/01/infeksinosokomial.html (13 Januari Pukul 19.41 WIB).

Agnes Sri Harti, 2015, Mikrobiologi Kesehatan, Yogyakarta: CV. Andi Offset.

Annisa Fitriani, dan Inayati Habib, Perbedaan Efektivitas Cuci Tangan Menggunakan Base Gel, Alkohol 70\%, Antis ${ }^{\circledR}$ dan Gel Propolis Lebah Berdasarkan Angka Kuman, at thesis.umy.ac.id/datapublik/t63265.pdf (13 Januari 2017 Pukul 16.21 WIB).

Darmadi, 2008, Infeksi Nosokomial: Problematika dan Pengendaliannya, Jakarta: Salemba Medika.

Departemen Kesehatan, 2003, Pedoman Pelaksanaan Kewaspadaan Universal di Pelayanan Kesehatan, Jakarta, at www.indonesian-publichealth.com/ mewaspadai-infeksi-nosokomial/ (12 Januari 2017 Pukul 10.13 WIB).

Fajar Ardi Desiyanto, dan Sitti Nur Djanah, 2013, Evektivitas Mencuci Tangan Menggunakan Cairan Pembersih Tangan Antiseptik (Hand Sanitazer) Terhadap Jumlah Angka Kuman, Kesehatan Masyarakat, Vol. 7 / No. 2, September 2013, at www.e-jurnal.com/2015/05/efektivitas-mencucitangan-menggunakan.html (12 Januari 2017 Pukul 13.05 WIB).

H. Jeffrey F., L., 2012, Perbandingan Evektifitas Handrub Softa-Man ${ }^{\circledR}$ dan Formula Handrub Moewardi Terhadap Angka Kuman di RSUD Dr.
Moewardi, Universitas Sebelas Maret Surakarta, at https://digilib.uns.ac.id/dokumen/download/29516/Nj IyMTk=/Perbandingan-Efektivitas-Handrub-SoftaMan-Dan-Formula-Handrub-Moewardi-TerhadapAngka-Kuman-Di-Rsud-Dr-Moewardi-abstrak.pdf (17 Januari 2017 Pukul 22.55 WIB).

http://dr-suparyanto.blogspot.co.id/2011/03/konsepdesinfektan.html diakses 20 Januari Pukul 21.49 WIB.

https://id.scribd.com/doc/118108549/Praktikpemeriksaan-angka-kuman-makanan diakses 20 Januari 2017 Pukul 19.23 WIB.

I Gusti Agung Gde Oka Ardana, 2016, Program Penyadaran Kepatuhan Cuci Tangan dapat Meningkatkan Pengetahuan Cuci Tangan, Menurunkan Jumlah Koloni dan Bakteri Staphylococcus aureus pada Tangan Co Ass FKG Unmas Denpasar, Universitas Udayana, at www.pps.unud.ac.id/thesis/pdf_thesis/unud-16451965880652-tesis\%20oka\%20final.pdf (20 Januari Pukul 16.02 WIB).

Kementerian Kesehatan Republik Indonesia, 2011, Pedoman Pencegahan dan Pengendalian Infeksi di Rumah Sakit dan Fasilitas Kesehatan Lainnya, Jakarta: Kementerian Kesehatan Republik Indonesia.

Keputusan Menteri Kesehatan Republik Nomor 270 Tahun 2007 tentang Pedoman Manajerial Pencegahan dan Pengendalian Infeksi di Rumah Sakit dan Fasilitas Kesehatan Lain, Jakarta.

Michael J., Pelczar, dan E. C. S. Chan, 2008, Dasardasar Mikroorganisme, Jakarta: Universitas Indonesia Press.

Muhammad Akim, 2013, Efektivitas Hand Sanitizer Dibanding Mencuci Tangan Memakai Sabun Dalam Menjaga Kebersihan Tangan pada Mahasiswa Fakultas Kedokteran Universitas Sumatera Utara Angkatan 2012, Universitas Sumatera Utara, at http://repository.usu.ac.id/handle/ 123456789/46146 (16 Januari Pukul 14.31 WIB).

Neil A., Campbell, Jane B. Reece, \& Lawrence G. Mitchell, 2003, Biologi, Jilid 2, Edisi Kelima, Alih Bahasa: Wasmen, Jakarta: Penerbit Erlangga.

Pipit Puspita Dewi, 2014, Perbedaan Angka Kuman dan Coass dan Perawat Setelah Melakukan Tindakan Hand Hygiene, program Studi Pendidikan Dokter Fakultas Kedokteran dan Ilmu Kesehatan Universitas Muhammadiyah Yogyakarta, at thesis.umy.ac.id/datapublik/t35431.docx diakses (6 Juli 2017 Pukul 20.35 WIB).

Ratna Nugraheni, Suhartono dan Sriwinarni, 2012, Infeksi Nosokomial di RSUD Setjonegoro Kabupaten Wonosobo, Media Kesehatan Masyarakat Indonesia, Vol. 11/ No. 1, April 2012, at ejournal.undip.ac.id/ index.php/ mkmi/article/download/ 6169/5222 (12 Januari 2017 Pukul 14.23 WIB). 
Retno Wuriyatmi, 2016, Perbandingan Efektifitas Handrub Septic Gel® dan FormulaRW Terhadap Penurunan Angka Kuman pada Tangan di RSUD Ajibarang Tahun 2016, Jurusan Kesehatan Lingkungan Poltekkes Kemenkes Semarang.

Robert R., Harr, 2002, Resensi Ilmu Laboratorium Klinis, Alih Bahasa: Huriawati Hartanto, Editor Edisi Bahasa Indonesia: Erlan, Lidya I. Mandera, Jakarta: EGC.

Saifuddin, 2005, Panduan Pencegahan Infeksi untuk Fasilitas Pelayanan Kesehatan dengan Sumber Daya Terbatas, Jakarta: Yayasan Bina Pustaka Sarwono Prawirohardjo, at http://dr-suparyanto.blogspot.co.id/ 2011/03/konsep-desinfektan.html diakses (20 Januari Pukul 21.49 WIB).

Srikandi Fardiaz, 1992, Polusi Air dan Udara, Yogyakarta: Kanisius.

Tri Cahyono, 2014, Pedoman Penulisan Proposal Penelitian dan Karya Tulis Ilmiah/ Skripsi, Edisi Revisi Ketiga, Purwokerto: Kementerian Kesehatan
Republik Indonesia Politeknik Kesehatan Kemenkes Semarang Jurusan Kesehatan Lingkungan Purwokerto.

Undang-undang Republik Indonesia Nomor 44 Tahun 2009 tentang Rumah Sakit, Jakarta: Presiden.

Universitas Muhamadiyah Semarang, at http://digilib. unimus.ac.id/ files/ disk1/ 107/ jtptunimus-gdlwahyunengs-5324-2-bab2.pdf (18 Januari 2017 Pukul 01.41 WIB).

Universitas Sumatera Utara, at http://repository. usu.ac.id/bitstream/123456789/26375/4/Chapter\%20I I.pdf (18 Januari 2017 Pukul 10.17 WIB).

, at http://repository. usu.ac.id/bitstream/123456789/25630/4/Chapter\%20I I.pdf (19 Januari 2017 Pukul 15.05 WIB).

WHO, 2009, Guidelines on Hand Hygiene in Healthcare, at http://www.lean-indonesia.com/ 2013/03/alcohol-handrub-cairan-pembersihtangan.html (20 Januari 2017 Pukul 15.02 WIB). 